\title{
Crushed concrete as concrete aggregate in the manufacture of reinforced concrete structures
}

\author{
Myhammet Fachratov ${ }^{1, *}$ \\ ${ }^{1}$ Moscow State University of Civil Engineering, Yaroslavskoe shosse, 26, Moscow, 129337, Russia
}

\begin{abstract}
The methods of waste recycled usage, especially, usage of secondary crushed stone made of crushed concrete scrap are becoming ever more relevant with every passing year. Imported concrete aggregate volumes can be reduced by $15-30 \%$ due to usage of secondary crushed stone. Consideration of industrial waste problem and methods of solving this problem by using waste in construction industry including secondary crushed stone made of crushed concrete scrap. Annually, about 11.5 million tons of construction waste is generated in Moscow, in the near future concrete scrap volumes are expected to rise to 13-15 million tons per year because of building demolition, reconstruction, overhaul and piling of reject structures.
\end{abstract}

\section{Introduction and literature review}

According to statistical data, the following construction wastes are generated as a result of demolition, reconstruction, construction of new buildings and structures: concrete and reinforced concrete, littered soil, stone waste, asphalt, wood waste, ceramic, glass, paper waste (Figure 1) [1,2].

Usage of construction waste in the industry makes the end-product cheaper because first, waste transportation and storage are cost-free; second, construction waste is a free and environment-friendly raw material; ground area capacities are spared due to there being no waste at landfill sites, thereby improving the ecological situation.

Originally, P.I. Gluzhge analyzed and suggested using crushed concrete as concrete aggregate for two reasons: 1) during the war years, a lot of construction waste was produced because of buildings and structures bombing; 2) construction material enterprises were also destroyed. R.R. Ploeger and O.R. Graph conducted similar research in 1947-1948 in Germany.

\section{Materials and methods. Results and discussion}

The crushing of concrete and reinforced concrete scrap produces crushed stone, each grain of which consists of large natural aggregate, encircled with cement-sand grout.

Secondary crushed stone, obtained by crushing reinforced concrete slabs of demolished five-storey buildings, was studied.

\footnotetext{
*Corresponding author: fahratov@mail.ru
} 
Secondary crushed stone's fine fraction contains not enough primary aggregate, while 1020 and $20-40 \mathrm{~mm}$ fractions are approximately equal in their aggregates and binder ratio. There is more than half of mortar fraction in such crushed stone.

Particle-size study of crushed concrete showed that crushed stone obtained from concrete with 5-20 mm and 10-40 mm fraction meets the requirements of GOST 8267-93 [4].
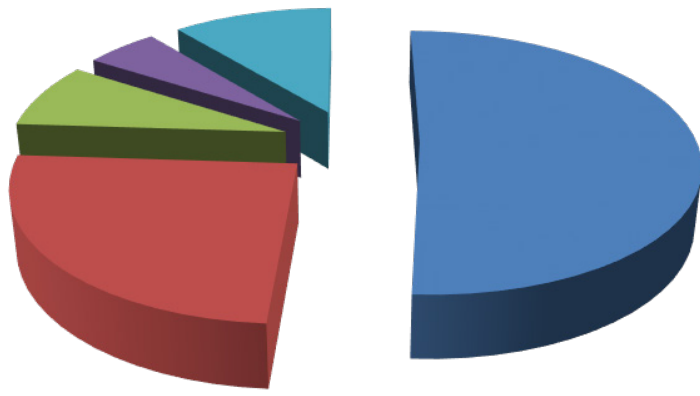

concrete and reinforced concrete $51 \%$

- littered soil $25 \%$

rock materials $8 \%$

asphalt 5\%

mother wastes $11 \%$

Fig. 1. Construction waste in percentage correlation, generated during demolition, reconstruction and new construction.

The average density, according to GOST 8267-93 [4], is not less than $2 \mathrm{~g} / \mathrm{cm}^{3}$ and not more than $3 \mathrm{~g} / \mathrm{cm}^{3}$, which is the optimal average density for heavy concrete's aggregates;

It is established that content of weak and flaky grains in crushed stone of concrete is less than $15 \%$, it meets the requirements of 300-400 quality class of crushed stone.

Crushability of crushed stone of concrete is of 400 quality class and it can be used for construction works and production of concrete of B30 and below strength quality.

Wear capacity of crushed stone is of I3 and I4 quality class.

It is established that crushed stone's frost-resistance meets frost-resistance quality class from 15 to 125 , depending on fraction.

Homogeneity evaluation of crushed stone by average density and crushability showed that the variation coefficient is equal to $8 \%$.

Secondary crushed stone has best efficiency ratio if concrete and reinforced concrete scrap:

- is delivered, processed and stored free from admixture, that means concrete-to-crushed stone process is cleared from bobs and other contaminants

- underwent two-stage processing in grinder, that means weak mortar phase was maximally removed from crushed stone by grinding screening processes. 1.

The physical and chemical properties of concrete scrap aggregates are presented in Table

5-10 $\mathrm{mm}$ fracture comparative study, based on the results of the research, was carried out. The results of the study are presented in Table 2.

It follows that secondary crushed stone can be used as concrete aggregate, since the specified requirements for heavy concrete's crushed stone according to GOST 8267-93 [4] are observed.

After analyzing secondary crushed-stone concrete of crushed concrete, we selected and tested various mixtures with different cement-water ratios and different fluidity values. 
Table 1. Concrete aggregators properties.

\begin{tabular}{|c|c|c|c|c|}
\hline Fraction & $5-10$ & $5-20$ & $10-20$ & $20-40$ \\
\hline Reaperties density $\left(\mathrm{g} / \mathrm{m}^{3}\right)$ & 2.52 & 2.53 & 2.55 & 2.53 \\
\hline $\begin{array}{c}\text { Average density } \\
\left(\mathrm{g} / \mathrm{m}^{3}\right)\end{array}$ & 2.13 & 2.16 & 2.21 & 2.26 \\
\hline $\begin{array}{c}\text { Poured density } \\
\left(\mathrm{g} / \mathrm{m}^{3}\right)\end{array}$ & 1.34 & 1.32 & 1.33 & 1.36 \\
\hline Porosity $(\%)$ & 15.48 & 14.62 & 13.33 & 10.67 \\
\hline Void content $(\%)$ & 37.1 & 38.89 & 39.82 & 39.82 \\
\hline $\begin{array}{c}\text { Water absorption } \\
(\%)\end{array}$ & 7.9 & 5.8 & 3.7 & 2.5 \\
\hline Humidity (\%) & 3.5 & 3.5 & 3.6 & 3.6 \\
\hline
\end{tabular}

Table 2. Natural crushed stone and secondary crushed stone comparison according to physical-mechanical properties.

\begin{tabular}{|c|c|c|c|c|}
\hline Properties & $\begin{array}{c}\text { Crushed stone } \\
\text { of consolidated } \\
\text { rock (gravel) }\end{array}$ & $\begin{array}{c}\text { Secondary } \\
\text { crushed } \\
\text { stone }\end{array}$ & $\begin{array}{c}\text { Crushed stone } \\
\text { of porous rock }\end{array}$ & $\begin{array}{c}\text { Expanded } \\
\text { pearlite crushed } \\
\text { stone }\end{array}$ \\
\hline GOST requirements & $8267-93[4]$ & - & $22263-76[5]$ & $10832-91[6]$ \\
\hline Average density & 2.65 & 2.13 & 2 & 2.05 \\
\hline $\begin{array}{c}\text { Durability class } \\
\text { according to } \\
\text { crushability }\end{array}$ & 1000 & 400 & 400 & 400 \\
\hline $\begin{array}{c}\text { Content laminar and } \\
\text { needle-shaped grains \% }\end{array}$ & 9.4 & 40 & 30 & 25.5 \\
\hline Flour and clay particles & 0.4 & 2.5 & 2.7 & 2.5 \\
\hline Frost-resistance, cycles & 200 & 25 & 15 & 25 \\
\hline Water absorption \% & 4 & 7.9 & 9.45 & 7.5 \\
\hline
\end{tabular}

Extensive use of natural resources by man, processing of huge amounts of rock mass, water and air disturbs ecology and is accompanied by a constant waste growth. Production waste disposal spending accounts for an average $8-10 \%$ of the product cost.

Construction industry, where raw materials' specific weight reaches $50 \%$, is the most high-capacity industrial waste use industry. It allows large amounts of waste to be utilized. Most types of waste are close to a natural raw material in terms of properties and composition.

As a rule, waste processing (especially man-caused) in raw materials for building materials is cheaper than natural materials. But it depends.

Processing of construction waste, generated during the demolition of obsolete and wornout buildings and structures, is more cost-intensive than making crushed rock from rocks. As is known, this is related to the necessity of pre-erection works, the use of more powerful and expensive equipment, the extraction of reinforcement and others. However, when one accounts for expenses involved in disposal of construction waste (transportation costs, landfilling cost, environmental damage caused by land pollution, relative environmental 
damage caused by emissions release during transportation), it appears that secondary crushed stone is $15-20 \%$ as cheap as natural crushed stone. Moreover, its use in road works for the underlying layer, proved effective. Treatment charges and quality of secondary crushed stone depend on the method of demolition of buildings and structures (demolition, explosion, dismantling), the type of crushing stations (auger-drill, rotor, pipe, etc.), the separability of material sorting before crushing and some other difficult factors.

Crushed stone of crushed concrete contains a considerable amount of mortar component, alongside that, initial grain and grout contact zone, which is the least rigid and the most porous crushed stone grain, significantly reduces physical-mechanical properties of $\mathrm{F} \mathrm{Mp3}$ crushed stone from 200 to 15 cycles, crushability from 12 to 24 .

At the same time, concrete with secondary crushed stone has more than $200 \mathrm{~kg} / \mathrm{cm}^{2}$ durability, more than 125 cycles of frost-resistance. This can be explained by the fact that the current methods and evaluation criteria for natural crushed stone are not suitable for qualitative assessment of crushed stone, the quality of which should be assessed indirectly by the physical-mechanical properties of concrete produced with secondary crushed stone. It is necessary to develop special regulatory documents, considering the specific properties of crushed stone.

However, the ecological issue remains crucial not only at the stage of building material production, but also at the stage of waste disposal. The problem of construction waste disposal is of great concern in the entire civilized world. According to the international organization RILEM the annual volume of concrete scrap alone is more than 360 million tons in the EU countries, the USA and Japan.

Thus, pre-fab panel buildings with a total area of about 36 million $\mathrm{m} 2$ used to be built in Moscow; some of these buildings were built of vibration-rolled concrete and other panels (K7, P-32, II-35 buildings). These buildings are both obsolete and worn-out physically and morally and, therefore, they have practically been demolished today.

The expedience of processing concrete and reinforced concrete left from demolished buildings and obtaining secondary crushed stone is economically feasible. It is cheaper to use construction waste because first, waste transportation and storage are cost-free; second, construction waste is a free and environment-friendly raw material; ground area capacities are spared due to there being no waste at landfill sites, thereby improving the ecological situation.

\section{Conclusions}

By summarizing domestic and foreign accomplishments one may be able to find a solution to the man-caused waste processing and disposal problem through the creation of an integrated management system for the rational use of material resources. Its goal is a constant development of resource-saving methods of economic operations. An integral part of this system is the integrated management system for the rational use of secondary raw materials, including concrete waste.

After analyzing secondary crushed-stone concrete of crushed concrete, we selected and tested various mixtures with different cement-water ratios and different fluidity values (Table3). Physical properties of concrete with secondary crushed stone are equal to concrete GOST 25192, GOST 26633-91.

Construction waste and waste from demolished worn-out five-storey buildings is a topic that should be considered separately, since it is a problem on the national level, it is necessary to develop a unified accounting scheme for waste disposal, and its rational use in future as a resource-energy-saving technology in the production of construction materials for products and structures. 
Table 3. Composition and basic physical properties of concrete with secondary crushed stone.

\begin{tabular}{|c|c|c|c|c|c|}
\hline \multirow{2}{*}{$\mathrm{N}$} & \multirow{2}{*}{ Specification } & \multirow{2}{*}{$\begin{array}{c}\text { Unit of } \\
\text { measurement }\end{array}$} & \multicolumn{3}{|c|}{ Structure code } \\
\hline & & & Test specimen & A-1 & A-2 \\
\hline 1 & $\begin{array}{l}\text { Consumption of materials per } \\
1 \mathrm{~m} \text { of concrete mix }\end{array}$ & & & & \\
\hline 1.1 & Cement & $\mathrm{kg}$ & 330 & 540 & 392 \\
\hline 1.2 & $\begin{array}{l}\text { Secondary crushed stone } \\
\text { fracture } 5-20 \mathrm{~mm}\end{array}$ & $\mathrm{~kg}$ & - & 960 & 1011 \\
\hline 1.3 & $\begin{array}{l}\text { Natural crushed stone GOST } \\
8276-93\end{array}$ & $\mathrm{~kg}$ & 980 & - & - \\
\hline 1.4 & Sand & $\mathrm{kg}$ & 852 & 590 & 708 \\
\hline 1.5 & Water & $\mathrm{kg}$ & 165 & 210 & 187 \\
\hline & $\mathrm{C}-3$ & $\mathrm{~kg}$ & - & - & 2.17 \\
\hline 2 & Cement-water ratio & - & 0.49 & 0.39 & 0.48 \\
\hline 3 & Fluidity of concrete & $\mathrm{Kg} / \mathrm{m}^{3}$ & $6-8$ & $6-7$ & $6-8$ \\
\hline 4 & Fluidity class & - & $\mathrm{P} 2$ & $\mathrm{P} 2$ & $\mathrm{P} 2$ \\
\hline 5 & Average density of concrete mix & $\mathrm{Kg} / \mathrm{m} 3$ & 2327 & 2300 & 2300 \\
\hline 6 & $\begin{array}{l}\text { Strength of compression at age } \\
7 \text { days } \\
28 \text { days }\end{array}$ & Mpa & $\begin{array}{l}27.1 \\
36.9\end{array}$ & $\begin{array}{l}25.4 \\
35.3\end{array}$ & $\begin{array}{l}25.4 \\
35.3\end{array}$ \\
\hline 7 & $\begin{array}{l}\text { Bending resistance at age } \\
7 \text { days } \\
28 \text { days }\end{array}$ & Mpa & $\begin{array}{l}2.8 \\
3.8\end{array}$ & $\begin{array}{l}2.6 \\
3.6\end{array}$ & $\begin{array}{l}2.6 \\
3.6\end{array}$ \\
\hline 8 & $\begin{array}{l}\text { Class of compression breaking } \\
\text { strength }\end{array}$ & - & B25 & B25 & B25 \\
\hline
\end{tabular}

\section{References}

1. Russian Standard GOST 25916 Resources, material secondary. Terms and Definitions.

2. Russian Standard GOST 8267 Crushed stone and gravel from dense rocks for construction works. Technical conditions.

3. Russian Standard GOST 25192 Concretes. Classification and general technical requirements.

4. Russian Standard GOST 26633 Heavy and fine-grained concretes. Technical conditions.

5. A.A. Kalchin, M.A. Fakhratov, E.V. Kalmykova, A.N. Kravchenko, International Concrete Production Magazine, 2 (2008)

6. A.A. Kalchin, M.A. Fakhratov, V.I. Sokhryakov, A.A. Belov, StroyProfil 97, 5-6 (2012)

7. M.A. Fakhratov, O.S. Kikava, E.V. Kalmykova, Problems of ecology and utilization of used concrete and reinforced concrete. Conference of creative youth. New ideas for the development of concrete and reinforced concrete structures. 